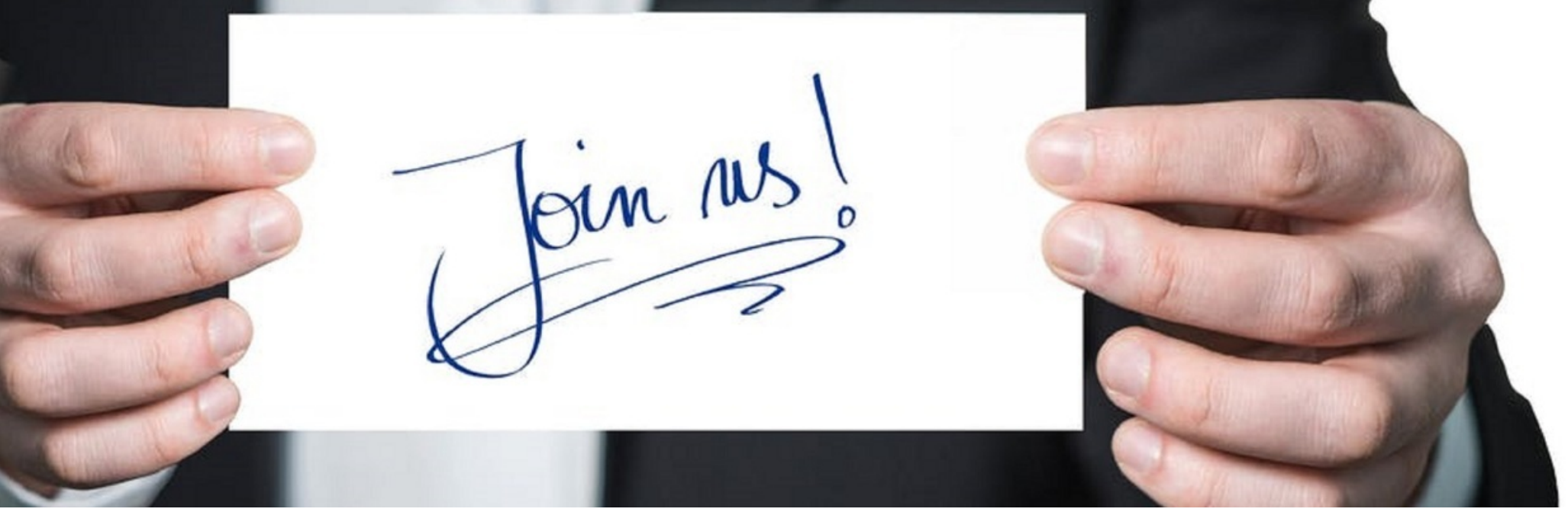

\title{
Bright minds for a better world! Demetrios Prize 2019
}

Authors: Roland Mertelsmann, Gerhard Steinmann, Stephan Seiler

Submitted: 27. June 2019

Published: 28. June 2019

Volume: 6

Issue: 6

Affiliation: Uniklinik Freiburg, Med 1

Languages:

Keywords: German

Categories: Demetrios, competition, Award, Prize 2019 Demetrios Project, News and Views

DOI: 10.17160/josha.6.6.578

Abstract:

On 06.07.19 from 20:00 the "International Academy of Sciences, Humanities, and Arts" IASHA invites you to the Horst-Linde-Saal in Bad Krozingen for a concert and poetry evening with the "Swing-Kids" from St. Gallen in cooperation with the Oberlin Junior Orchestra Freiburg \& Marie Brendle as well as the poetess Zazie-Charlotte Pfeiffer. In addition to the artistic program, this festive evening also honors this year's Academy prizewinners.

\section{JOSHA Joumal o s Science, Humanities and Arts}




\section{Bright minds for a better world}

Am 06.07.19 ab 20:00 Uhr lädt die "International Academy of Sciences, Humanities and Arts" IASHA in den HorstLinde-Saal in Bad Krozingen zu einem Konzert-, und Poesieabend mit den "Swing-Kids" aus St. Gallen in Kooperation mit dem Oberlin Junior Orchester Freiburg \& Marie Brendle sowie der Poetin Zazie-Charlotte Pfeiffer ein.

Neben dem künstlerischen Programm werden an diesem feierlichen Abend auch die diesjährigen Preisträger der Akademie geehrt.

Einlass ab 19:30 Uhr I Horst-Linde-Saal Kurhaus Bad Krozingen I freie Platzwahl I Spendenbasis

Auf einen erfolgreichen und unterhaltsamen Abend mit einem diversen Programm aus Kunst und Wissenschaft!

Wir freuen uns auf Sie und auf einen lebhaften Abend voller „bright minds“! 
